\title{
Study of Iron Pipe Corrosion in Municipal Water Distribution System and Its Effect
}

\author{
Enkuahone Abebe Alamineh \\ Department of Chemical Engineering, Debre Berhan University, Debre Berhan, Ethiopia \\ Email address: \\ enkuahone@dbu.edu.et, enkush2014@gmail.com, enkuahone1883@gmail.com \\ To cite this article: \\ Enkuahone Abebe Alamineh. Study of Iron Pipe Corrosion in Municipal Water Distribution System and Its Effect. American Journal of \\ Chemical Engineering. Vol. 6, No. 2, 2018, pp. 19-24. doi: 10.11648/j.ajche.20180602.11
}

Received: March 29, 2018; Accepted: April 15, 2018; Published: April 24, 2018

\begin{abstract}
Deterioration could lead to destruction of materials with chemical or electrochemical reaction as corrosion. Corrosion is one of the most complicated and costly problems facing in municipal drinking water utilities. A large number of parameters affected pipe corrosion, including water quality and composition, flow conditions, biological iron activity, and corrosion inhibitors. Corrosion scales play an important role in modifying water quality in drinking water distribution systems. The corrosion scales from old water pipe lines were analyzed for their structure and composition. This paper mainly studied the deposits found in water distribution system of Municipal and protection of corrosion methods as well as to preventive measurements of the iron pipe corrosion. The corrosion scales had a shell-like, enveloping layer, covering porous deposits of iron oxide phases. Catastrophic failures are obtained in water distribution systems, so major layer will be occurred. The ground water samples were drawn from the area and subjected to physical and chemical analysis and the analysis results were used to evaluate in laboratory works.
\end{abstract}

Keywords: Electrochemical, Corrosion, Iron Pipes

\section{Introduction}

Municipal is using cast iron pipes to transport potable water for several years, now days the iron pipe corrosion is a major problem in water distribution piping system. The majority of distribution system pipes are composed of iron material; cast iron $(38 \%)$, ductile iron $(22 \%)$, and steel $(5 \%$ [1]. Iron corrosion is an extremely complex process because of the large variability in distribution system conditions; a particular factor may be critical in one system but relatively unimportant in another system. Moreover, corrosion itself has several different manifestations and can be evaluated in many ways. In my studies on iron pipe corrosion have focused on different aspects of iron corrosion; pipe degradation measured by weight loss, oxygen consumption or corrosion current, scale formation measured by head loss or scale deposition, and by product release measured by iron concentration, color, staining, turbidity, or number of customer complaint [2].

While most people in urban cities of the country have access to piped water, Municipal still rely on groundwater for domestic use. Industrial effluents, if not treated and properly controlled can pollute ground water. Therefore, the ground water generally have poor quality water in the affected areas. Depending upon its specific chemistry, water can promote scaling, corrosion or both. Scaling is one of the most critical water quality issues in Municipal [3].

Scale can be formed from a variety of dissolved chemical species but two reliable indicators are hardness and alkalinity. Calcium carbonate is the most common form of scale deposition attributable to ground water used in residential geothermal heat pump systems. Two indices commonly used in the water treatment plant to evaluate the nature of a water source [4]. The Municipal drinking water comes from the ground water from wells have usually been insufficiently long contact with carbonate containing sediment. Dissolving of a material by a corrosive liquid is called chemical corrosion. The material continues to dissolve until either it is consumed or the liquid is saturated. The removing of metal atoms from a solid material as the result of an electric circuit is called electrochemical corrosion. In this form of corrosion, metal atoms lose electrons and become ions thus forming a byproduct. Electrochemical corrosion occurs most frequently in aqueous mediums, in 
which ions are present in water or moist air. In this process, an electric circuit is created and the system is called an electrochemical cell [5]. Corrosion is one of the most common problems affecting domestic water supplies. Iron and steel pipes have been used in Municipal water distribution systems for over many years. The main source of Iron pipe corrosion are particulate matter transported by water, dissolve oxygen, microbial activity, chlorides, sulphate and physicochemical reactions both at the pipe wall interface and within the water bulk. Most water distribution systems buildup of iron corrosion products inside the iron pipes. Corrosion scale/deposits not only restrict the flow of water but degrade the quality of water. The scales are porous deposits that are comprised of iron hydroxide phases. Some ways in which iron pipe corrosion scales can adversely affect the water quality in drinking water distribution pipes will be investigated in this research [6].

\section{Methods and Materials}

\subsection{Materials}

Material used to analyze water were steel pipe anode, copper cathode, water sample from internal corroded iron pipe line, and soil in box container (water bath), conductor (metal bath) between our pipe anode, direct source (DC power source) of electric current with the rectifier or transformer and gray cast iron.

\subsection{Chemicals}

Chemicals used for laboratory water test were: phenolphthalein ( $p$-solution); distilled water for preparing solution; sodium thiosulphate(t-solution); calcium hardness indicator; buffer solution; $0.02 \mathrm{NH}_{2} \mathrm{SO}_{4} ; 0.01 \mathrm{M}$ EDTA and methyl orange solution.

\subsection{Equipment Used in the Laboratory for Water Testing}

Equipment used in the laboratory for water testing were: measuring cylinder; $\mathrm{pH}$ meter; turbidity meter; conductive meter; $800 \mathrm{ml}$ beaker; glass road (string rod) and test-tube.

\subsection{Cathodes Protection Equipment}

The basic equipment used for cathodes protection work includes: corrosion and cathodes protection, galvanic anodes, or impressed current anodes and a rectifier, junction boxes where multiple anodes may come together, test stations for electronic access to cathodically protected structures, shunt resistors used for measuring current by application of Ohm's law, variable resistors used to adjust current throughout, a high-impedance (10 mega ohm minimum) portable voltmeter and wire leads.

\subsection{Methods}

There are three common methods used to control corrosion on pipelines are protective coatings and linings, cathode protection and materials selection $[7,8]$.
Coatings and lining: are principal tools for defending against corrosion. They are often applied in conjunction with cathode protection systems to provide the most cost-effective protection for pipelines [9].

Materials selection: refers to the selection and use of corrosion-resistant materials such as stainless steels, plastics, and special alloys to enhance the life span of structure such as a pipeline. Materials selection personnel must consider the desired life span of the structure as well as the environment in which the structure will exist. Corrosion inhibitors are substances that, when added to particular environments decrease the rate of attack of that environment on a material such as metal or steel reinforced concrete [10].

Cathodes protection: it is a technology that uses direct electrical current to counteract the normal external corrosion of a metal pipeline. Cathodes protection is a technique used to control the corrosion of a metal surface by making it the cathode of an electrochemical cell [11].

\subsubsection{Set up of Cathode Protection for Pipe Lines}

Anodes are arranged in a ground beds either distributed or in a deep vertical hole depending on several designs and field condition factors including current distribution requirements. The output direct current negative terminal is connected to the structure to be protected by the cathode protection. The rectifier output direct current positive cable is connected to the anodes [12]. The alternative current power cable is connected to the rectifier input terminal the output of the impendence current cathode protection system should be optimized to provide enough current to protect the target structure. An impudence current cathode protection system for pipe line consist of the direct current power source often an alternative current powered transformer rectifier and an anode. Arrow of an anode buried in the ground (the anode ground bed). The direct current power source typical have a direct current output of up to 50 Ampere and 50volt depending up on the size of pipe line, the coating quality, the positive direct current output terminal would be connect via cables to the anode array while another cable would connect the negative terminals of the rectifier to the pipe line [13].

\subsubsection{Water Quality Test}

Water makes about $90 \%$ of the final product and thus its quality directly affects the quality of the finished product. The quality parameters related to water could be physical and chemical and or micro biological among which the following were the common ones [13].

Turbidity: is the amount of particulate matter that is suspended in water. Turbidity was measured by turbidity meter.

Color: indicates the presence of decomposed organic material from natural or manmade sources and was measured by spectrophotometer.

Test and odor: are the result of decay of organic matter or intrusion of industrial and human wastes and were noticeable as water temperature increased.

Total Dissolved Solid (TDS): is the measure of inorganic salts and small amounts of organic matters present in a 
solution in water and was given in $\mathrm{mg} / \mathrm{l}$.

Electrical Conductivity: is a measure of the ability of water to conduct an electric current and was expressed in micro Siemens per centimeter. It was related to the concentration of TDS and major ions.

$\mathrm{pH}$ : is a measure of alkalinity or acidity of the water sample and is important to control corrosion and water treatment processes. $\mathrm{pH}$ of iron pipe was measured by $\mathrm{pH}$ meter.

Water hardness: sampling location was at corroded iron pipe water.

i. $100 \mathrm{ml}$ distilled water was measured and added to beaker.

ii. $1 \mathrm{ml}$ hardness buffer was added

iii. Two level of hardness indicator was added.

iv. Hardness was checked while the sample was turned to red

v. As buffer solution 12-15 drop of $10 \% \mathrm{NH}_{3}$ buffer was added.

Alkalinity: the following procedures were used.

$100 \mathrm{ml}$ was taken; 3 drop T- solution was added; 3 drop msolution was added; color change from colorless to light green was observed; using $0.02 \mathrm{NH}_{2} \mathrm{SO}_{4}$ was titrated; color change from light green to pink was observed; then volume of $0.02 \mathrm{NH}_{2} \mathrm{SO}_{4}$ was measured.

Conductivity of water: is an indirect measurement for finding the total dissolved solids in a water body in the conductivity of water sample (micro semien per centimeter) at $25^{\circ} \mathrm{C}$.

Dissolved oxygen: it was measured by dissolved oxygen meter.

\section{Result and Discussion}

The concentration of ions increased as the $\mathrm{pH}$ value of both of water sample were increased.

The total hardness of the corroded water as $\mathrm{CaCO}_{3}$ is $188.1 \mathrm{mg} / 1$. It was hard water based on the hardness of municipal was $303 \mathrm{ppm} \mathrm{CaCO}_{3}$. It showed that very hard water regarding to the outside of the country distributed water such as municipal water system.

\subsection{Water Quality}

In order to reach a better view on the variation of the treated water quality from the water treatment parameters and how they affected water stability, selected results from the determination of water quality parameters were discussed below. Alkalinity in water is due to the presence of weak acid systems that consume hydrogen ions produced by other reactions or produce hydrogen ions when they are needed by other reactions allowing chemical or biological. The water quality parameters compared with Municipal and WHO drinking water standards are shown table1, where the treated water is within these standards [13].

Table 1. Water quality parameters compared to municipal and WHO drinking water standards.

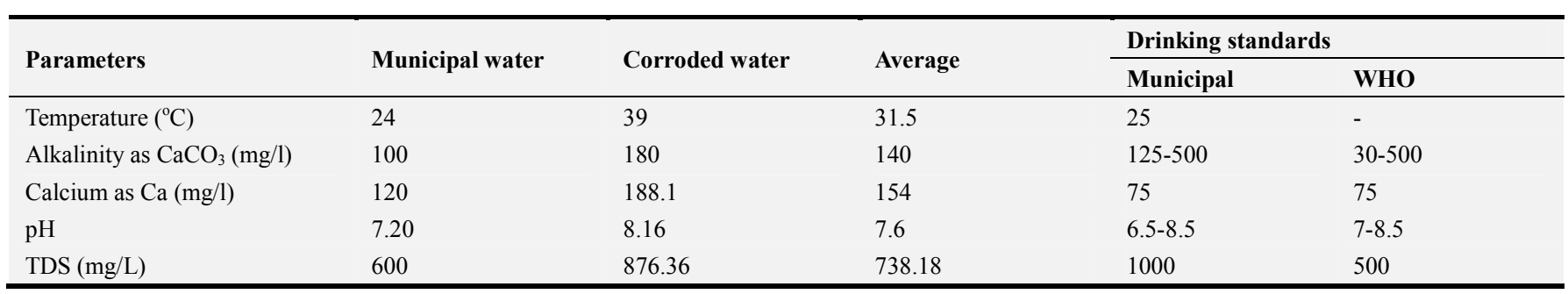

The primary source of alkalinity was the carbonate system, although phosphates, silicates, borates, carboxylates and other weak acid systems. Alkalinity was required in the coagulation process for the reaction of aluminum sulphate. From the recorded data the variation in alkalinity ranged between $100 \mathrm{mg} / \mathrm{l}$ to $180 \mathrm{mg} / \mathrm{l}$ with average $140 \mathrm{mg} / \mathrm{l}$ as $\mathrm{CaCO}_{3}$. Corrosively of water decreased as the alkalinity increased where it was necessary to provide a stable $\mathrm{pH}$ throughout the distribution system for corrosion control of metal pipes. Low iron corrosion rated and iron concentrations in the distribution systems have been associated with higher alkalinities. Calcium is the second most prevalent constituent in most surface waters and is generally among the most prevalent three or four ions in ground water [13].

Total dissolved solids (TDS) in water were due to inorganic salts. Principally these inorganic constituents were calcium, magnesium, sodium, and potassium salts of bicarbonate, chloride, sulfate, nitrate and phosphate. These compounds originate from weathering and leaching of rocks, soils and sediments. Also some of these compounds were added to the water in the treatment plants. From the recorded data the variation concentration of TDS ranged between 600 to $876.36 \mathrm{mg} / \mathrm{l}$ with an average of $738.18 \mathrm{mg} / \mathrm{l}$. higher water temperatures accelerated the rate of corrosion by increasing the rate of the cathode reaction. The chemical reaction rate generally was doubled for every $8^{\circ} \mathrm{C}$ increase in temperature [13].

\subsection{Corrosion Rate Calculation}

It is the speed at which metal deteriorates in specific environment. The rate of corrosion depended upon: environmental condition; type of metal and condition of metal; weight loss; the decrease metal weight during the reference time period; density of metal; area of the pipe initial and time. To calculate the corrosion rate from metal loss, RC (rate of corrosion) [23]. 


$$
\mathrm{RC}(\text { millimeter } / \text { year })=87.6 *\left(\frac{\text { weight }}{\text { density } * \text { area } * \text { time }}\right)
$$

$$
\begin{aligned}
& \text { Given }=1.30 \mathrm{~cm}, \mathrm{~A}=\frac{\pi \mathrm{D} 2}{4}=1.325 \mathrm{~cm}^{2} \\
& \mathrm{CP}=\text { corrosion potential }=300 \mathrm{mv}
\end{aligned}
$$

$$
\mathrm{W}=28,691.55 \mathrm{mg}
$$

Time $=1$ year $=8760 \mathrm{hr}$

$\mathrm{RC}=87.6 *\left(\frac{W}{D * A * T}\right)=87.6 *\left(\frac{28691.55}{8.02 * 1.325 * 8760}\right)=27$ micro ampere $(\mu \mathrm{A})$, sample from municipal water distribution of cast iron pipe. Where, $\mathrm{W}=$ weight loss in $\mathrm{mg}, \mathrm{d}=$ density in

Rate of corrosion for most metals increased with any increment of dissolved oxygen so the corrosion of pipe was increased [14].

\subsection{Cathodes Protection by Impressed Current}

Impressed current systems typically used a power source known as a rectifier. The rectifier converts AC power to DC power and provides adjustability to the system. Rectifiers were commonly equipped with meters to read current and voltage outputs. Circuit breakers, lightning arrestors and fuses were used to protect the unit from power surges and faults. Shunts were calibrated resistors used to measure $\mathrm{g} / \mathrm{cm}^{3}, \mathrm{~A}=$ area of sample in $\mathrm{cm}^{2}, \mathrm{~T}=$ time of exposure of pipe

current flow [15].

Table 2. Impressed current systems.

\begin{tabular}{lllll}
\hline S.No & Applied Current & Potential & Resistance & Days \\
\hline 1 & 3.18 & 0.836 & 0.22 & 1 \\
2 & 3.33 & 0.899 & 0.2702 & 2 \\
3 & 3.35 & 0.588 & 0.179 & 3 \\
4 & 3.36 & 0.598 & 0.1780 & 5 \\
5 & 3.37 & 0.604 & 0.1794 & 7 \\
6 & 3.35 & 0.5159 & 0.15476 & 9 \\
7 & 3.36 & 0.500 & 0.1492 & 11 \\
8 & 3.38 & 0.4022 & 0.11904 & 13 \\
\hline
\end{tabular}

Table 3. Corroded pipe and resistance.

\begin{tabular}{lllll}
\hline S.No & Applied Current & Potential & Resistance & Day \\
\hline 1 & 3.34 & 0.67 & 0.1497 & 1 \\
2 & 3.351 & 0.542 & 0.162 & 2 \\
3 & 3.354 & 0.598 & 0.178 & 3 \\
4 & 3.3654 & 0.698 & 0.208 & 5 \\
5 & 3.3665 & 0.799 & 0.238 & 7 \\
6 & 3.3673 & 0.897 & 0.267 & 9 \\
7 & 3.368 & 0.931 & 0.277 & 11 \\
8 & 3.373 & 0.9469 & 0.281 & 13 \\
\hline
\end{tabular}

steel pipe

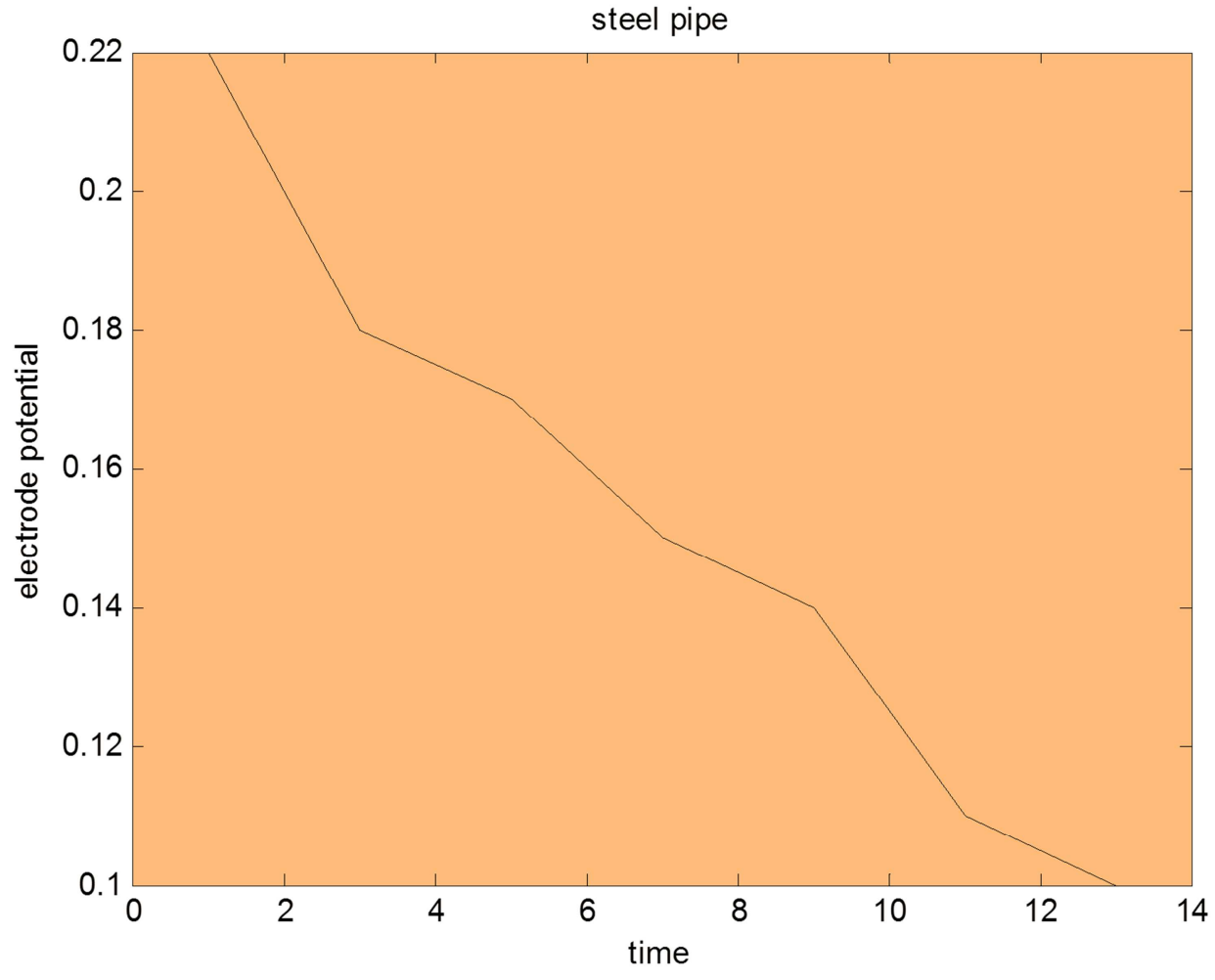

Figure 1. Electrode potential and time.

From the above figure it was concluded that as time increased electrode potential increased, as it increased ions concentration as a result of corrosion reaction 


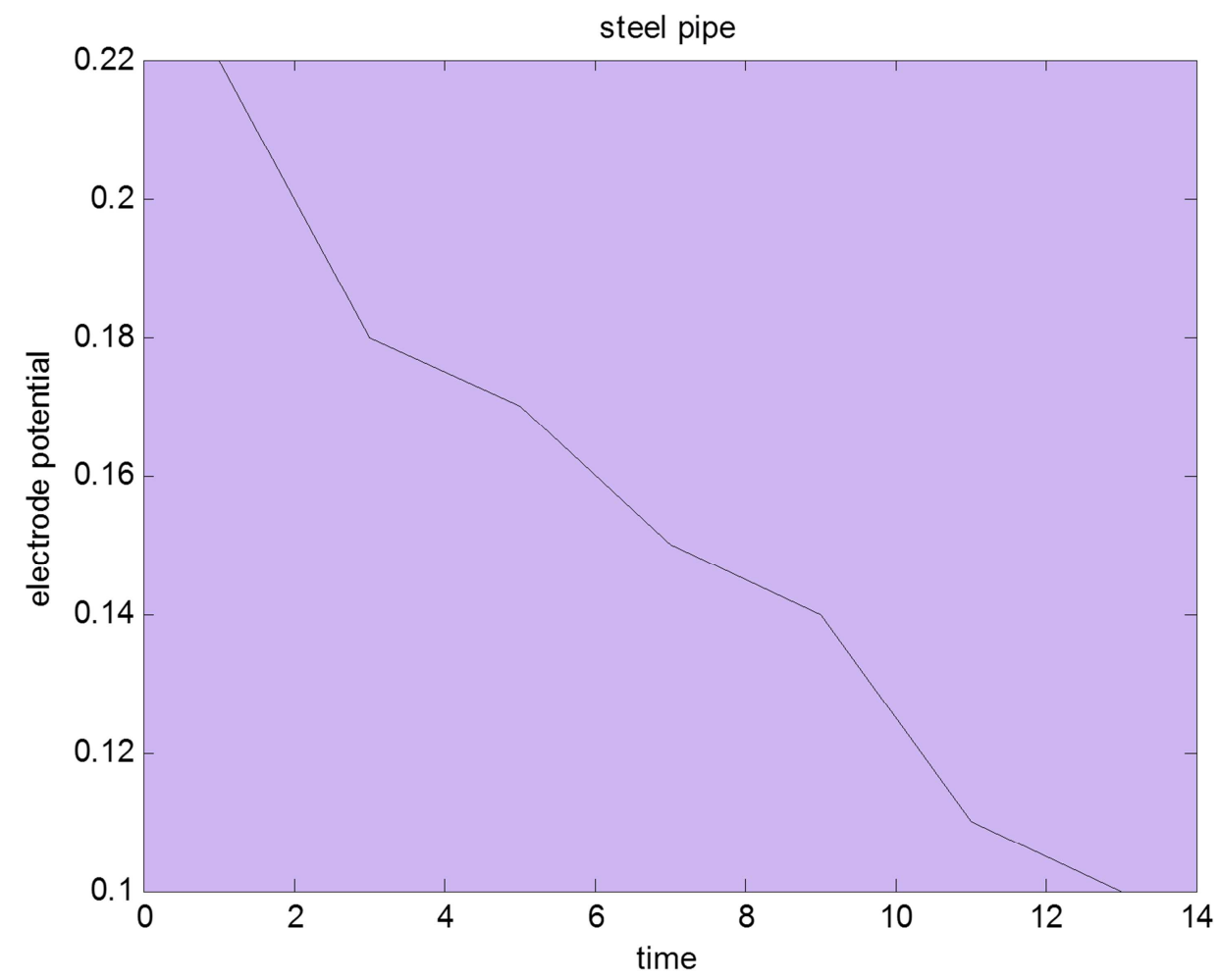

Figure 2. Comparison of resistance and time relationship in corrosion reaction.

From the above figure it was concluded that as time increased resistance decreased, as it increased ions concentration as a result of corrosion reaction.

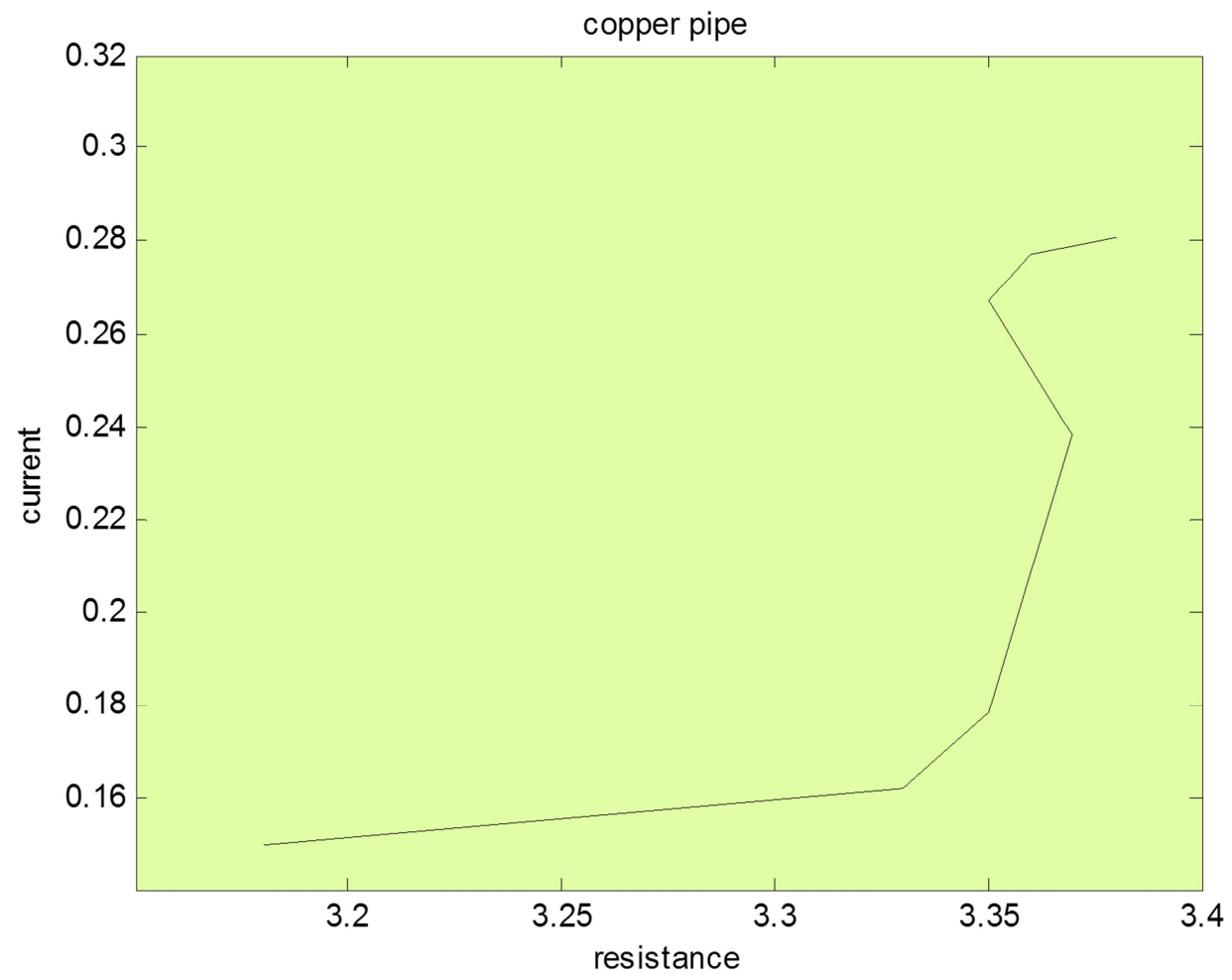

Figure 3. Comparison of current and time relationship in corrosion reaction.

From the above figure it was concluded that as time increased current increased, as it increased ions concentration as a result of corrosion reaction. 


\section{Conclusion}

The Municipal drinking water came from the ground water. This water was more hard water; so this experimental result showed that $188.1 \mathrm{mg} / 1$ as $\mathrm{CaCO} 3$ and the $\mathrm{pH}$ of the water was 8.16 from the corroded pipe sample at $28.9^{\circ} \mathrm{C}$ temperature. In low alkalinity and low $\mathrm{pH}$ water, elevating the $\mathrm{pH}$ to between 7 and 8 would beneficial in alleviating iron corrosion. Iron corrosion increased if the $\mathrm{pH}$ of the hard water was taken above 8 in the corroded iron pipe. So in the experiment was focused on cathode protection to decrease corrosion of iron pipe in drinking water distribution. Iron corrosion is an extremely complex process in underground iron pipe line. Because of the large variability in distribution system conditions; a particular factor may be critical in one system but relatively unimportant in another system. Moreover, corrosion itself has several different manifestations and can be evaluated in many ways. In this study it was focused on different aspects of iron corrosion and thus, pipe degradation was measured by weight loss, oxygen consumption, corrosion current, color, turbidity. Corrosion problems in humans in the short term damages the liver and kidneys over time. Corrosion can cause physical and mental development problems in children. In adults, it could lead to high blood pressure and kidney problems so this study was started based on the problem. The total cost of corrosion for the drinking water and sewer systems includes the cost of replacing aging infrastructure, the cost of unaccounted for water, the cost of external coatings, and the cost of cathode protection. So; the corrosion management was part of the overall management system, which should be concerned with the development, implementation, review and maintenance of the corrosion.

\section{References}

[1] G. Wranglen, "An Introduction to Corrosion and Protection of Metals" Chapman and Hall, New York (1985).

[2] M. Yamashita, H. Konishi, T. Kozakura, J. Mizuki and H. Uchidak, Corrosion Science, 47 (2009) 2492.

[3] Red Water Release in Drinking Water Distribution System. American Water Works Association, 97, 93-100. (2005)

[4] Namibian, A. Effect of Temperature Changes on Water-Main Breaks. Journal of Transportation Engineering, 120:2:312 (1994).

[5] Cottis, R. A., S. Turgoose, and R. Newman, Corrosion Testing Made Easy: Electrochemical Impedance and Noise, 1999.

[6] Holden, B.; Greet ham, M.; Croll, B. T. \& Scutt, J. The Effect of Changing Inter Process and Final Disinfection Reagents on Corrosion and Bio film Growth in Distribution Pipes.

[7] Water Science Technology, 32:8:213 (1995).

[8] W. Beackmann, W. Schwenk, W. Prinz: Handbook of Cathodic Corrosion Protection: Theory and Practice of Electrochemical Protection Processes, Gulf, And Houston 1997.
[9] H. H. Hulling and R. Winston, "Corrosion management and control" John Wiley and Sons, (2014).

[10] Richard Adie, Philosophical Magazine, 31 (2012) 351.

[11] “Faraday's Diary,” Vol. I -VII, 1820-1822, London-G. Bell and sons, 1932-1936.

[12] Corrosion/72 Technical Paper No. 72, Jones, D. A., “Analysis of Cathodes Protection Criteria."

[13] National Association of Corrosion Engineers. Houston, TX.

[14] J. Jankowski; electrochemical methods for corrosion rate determination under cathodes polarization Conditions. A Review, Part I. DC Methods, Corrosion Reviews, 20, 15 (2015).

[15] O. Riggs Jr., "Theoretical Aspects of Corrosion Inhibitors and inhibition", NACE, Houston, Texas (2008).

[16] M. G. Fontana and N. D. Greene, "Corrosion Engineering", McGraw Hill, New York (1978).

[17] D. A. Jones, Principles and Prevention of Corrosion, Prentice Hall, New York, 5 (2010).

[18] H. Davy, Journal of Nicholson's, 4 (1800) 337 and PHilosopHical Transactions of the Royal Society of London, $116(1826) 333$.

[19] Richard Adie, Philosophical Magazine, 31 (2012) 351.

[20] M. Stern and A. L. Geary, Journal of the Electrochemical Society, 104 (2012) 56.

[21] M. Stern, Corrosion, 14 (2008) 440.

[22] L. Gaiser and K. E. Heusier, Electrochemical Acta, 15 (2009) 161.

[23] K. E. Heusler and L. Gaiser, Journal of the Electrochemical Society, 117 (2007)762.

[24] P. Robert and Frankenthaler, Japan Seminar, March 10-12 (2013) 10 .

[25] AWWA (2009) Water Quality and Treatment. 3rd Edition, McGraw Hill Book Company, New York.

[26] Australian Drinking Water Guidelines (1996) National Water Quality Management Strategy. NHMRC and ARMCANZ, Canberra.

[27] Fang, W. The Research on Water Chemical Stabilization and Control Methods in the Urban Water Supply System (2004).

[28] AWWA; water quality and treatment $4^{\text {th }}$ edition, McGraw-Hill Book co. New York, 1990.

[29] J. Morgan: Cathodes Protection, 2nd ed., NACE, Houston 1987.

[30] R. Juchniewicz, J. Jankowski, K. Darowicki: Cathodic and Anodic Protection, in Corrosion and Environmental Degradation (M. Schütze, Ed.), Wiley-VCH, Weinheim 2000, Vol. I, pp. 383-470.

[31] J. Jankowski: Electrochemical Methods for Corrosion Rate Determination under Cathodic Polarization Conditions. A Review, Part I. DC Methods, Corrosion Reviews, 20, 15 (2002). 